\title{
Treasuring researchers
}

\author{
Images of 'real' scientists are rare in everyday society, and those of scientists who are also women are \\ doubly so. Could a female scientist on something as commonplace as a banknote help?
}

In a submission to the UK Parliament's Science and Technology Select Committee in September 1993 the Society of Biology baldly stated that "the under-representation of women in the science, technology, engineering and maths (STEM) workforce is a persistent phenomenon that transcends national boundaries and employment sectors, with implications for both society and the economy". It estimated that even in the biosciences, which are typically thought to have a lesser gender imbalance, only $15 \%$ of professors were female despite women constituting $61 \%$ of postgraduate students.

A casual glance suggests that plant biology has a higher proportion of women professors and lab heads than many disciplines, but we are a long way from parity. For example, of the fourteen presidents of the American Society of Plant Biology since 2002, only four have been women. The reasons behind the paucity of women achieving senior positions are many and complex, but a problem with image is certainly one. When asked to imagine a science professor most people will likely as not describe an old, white man with unkempt hair, essentially an amalgam of late period Albert Einstein and Emmett 'Doc' Brown from Back to the Future.

One attempt to raise the visibility of real scientists who are also women is the campaign to have a portrait of the inspirational geneticist and Nobel laureate who discovered transposable elements, Barbara McClintock, on the US\$10 bill. At first sight this seems a quixotic idea. No woman has ever featured on an American banknote. Only one scientist, Benjamin Franklin, has been so honoured, although more for his signature on the Declaration of Independence than his experiments with electricity, or his invention of the glass armonica. In fact only two people who lived as recently as the twentieth century have adorned US paper currency, William
McKinley who died in 1901 and Grover Cleveland who died in 1908 - making him just contemporary with McClintock who was born in 1902 .

However on 17 June Jack Lew, Secretary to the Treasury, announced that the new design of the US $\$ 10$ bill, which will come into circulation in 2020, would have a portrait of a woman to celebrate the centenary of the passage of the nineteenth amendment to the US constitution, which gave women the right to vote. Since then the Treasury has been taking suggestions and opinions as to who that woman might be. Barbara McClintock is certainly a strong candidate, but there is stiff competition
What precedents are there for putting women and/or plant scientists on banknotes? Double Nobel laureate Marie Curie appeared on a 500F note in France and on the 20,000zl note in Poland but it would be difficult to claim her as a plant scientist. Charles Darwin appears on the $\mathrm{UK} £ 10$ note and Carolus Linnaeus graces the Swedish $100 \mathrm{kr}$, while representing true botanists the Uruguayan Dámaso Antonio Larrañaga appears on the 2,000 pesos; José Celestino Mutis was on the 2,000 pesetas until Spain adopted the Euro in 2002, and Joseph Banks although an Englishman was for many years seen on the Australian \$5 note by virtue of his extensive involvement in the flora, and colonization, of that country. However, the only female plant biologist to grace currency was Maria Sibylla Merian, a portrait of whom was borne by the German DM500 note between 1992 and 2002.

Merian was a botanical illustrator and entomologist who lived in Germany and the from anti-slavery and civil rights activists like Susan B. Anthony, Harriet Tubman, Rosa Parks and Ida Wells. Other candidates include the deaf/blind writer and activist Helen Keller; founder of the Girl Scouts, Juliette Gordon Low; and politician Eleanor Roosevelt. The current front runner (at least on Twitter) seems to be Clara Barton the American Civil War nurse and founder of the American Red Cross.

The campaign to put 'Barbara on the Bill' was started by Don Gibson, a PhD student at UC Davis. He has no doubts about the strength of her case. "McClintock's research blew up how scientists thought genes worked, leading to fundamental insights on genetic diseases that now help create medicines and save lives," he says "In an age when Americans thirst for inspiring life stories of innovation and perseverance in the face of inequalities and challenges, Barbara McClintock's is one to celebrate. "
Netherlands between 1647 and 1717. She was unusual for her time, living much of her life as an independent woman following separation from her husband in her late 30s. In 1699 she travelled to Surinam in South America where she drew and recorded the flora and fauna of the country, and became an early ethnobotanist recording the native names for local plants and describing their uses by the indigenous peoples.

It would be wonderful to see Barbara McClintock's face staring out from the new US $\$ 10$ bill so go and sign the petition (http://www.barbaraonthebill.com). But even if achieved this should be seen not as an end but merely a step towards placing real scientists of whatever sex or origin side by side with the politicians and artists that currently dominate our national cultures, of which bank notes are a pervasive yet almost subliminal part. 